\title{
Dimensions, diversity and ecology of aquatic mycobiome*
}

\author{
K.R. Sridhar \\ Department of Biosciences, Mangalore University, Mangalagangotri, Mangalore, India \\ Centre for Environmental Studies, Yenepoya University, Mangalore, India \\ Corresponding author Email: kandikere@gmail.com
}

(Submitted on March 12, 2020; Accepted on May 24, 2020)

\begin{abstract}
Fungi being structurally, functionally and phylogenetically diverse, occupied a wide range of biomes worldwide. It is realized that evaluation of diversity, structure and function of fungal consortium (mycobiome) in an ecosystem will provide wider perspective. Assessment of core-group (major/keystone), less frequent (rare) and cryptic (hidden) fungi and their interaction in a biome will portray ecosystem functions more precisely. Aquatic mycota are overlooked in spite of their potential role in recycling organic matter, biogeochemical cycles, linking food webs and production of precious metabolites. Improved methodology and precision to understand the morphology, physiology, biochemistry, ecology and mutualism has driven the attention of mycologists and ecologists towards aquatic mycobiome recently. Aquatic mycota serve in the ecosystem as communities, hence their dynamics, spatiotemporal dimensions, mutual interactions and energetics will be of prime significance in ecosystem services. This contribution mainly emphasizes highlighting the dimensions, diversity, ecology and functions of filamentous fungi in different aquatic ecosystems.
\end{abstract}

Keywords: Aquatic fungi, decomposition, ecological functions, human interference, Indian subcontinent

\section{INTRODUCTION}

Fungi are evolutionarily diverse, adaptable and ubiquitous in global ecological niches similar to flora and fauna (NaranjoOrtiz and Gabaldón, 2019). Structure, diversity and combination of mycobiome vary greatly across the terrestrial and aquatic ecosystems. Despite nearly two-third earth surface covered with aquatic bodies (rivers, streams, reservoirs and oceans), only about 3050-4150 species of fungi have been reported (Shearer et al., 2007; Jones et al., 2014). Aquatic fungi are those which depend on aquatic bodies for entire or partial completion of their life cycle. Owing to occurrence of several freshwater/terrestrial fungi in saline habitats, definition proposed by Johnson and Sparrow (1961) has been broadened by Pang et al. (2016). Aquatic fungi have been recognized as indwellers, versatile and periodic immigrants depending on the degree of adaptation (Park, 1972). They are highly diverse owing to their ecological, phylogenetic and morphological characteristics (Shearer et al., 2007; Jones et al., 2009). Fungal diversity, role in food web and ecological services are overlooked in aquatic biology as well as biogeochemical processes (Grossart and Rojas-Jimenez, 2016; Grossart et al., 2019). However, eukaryotic fungal molecular sequences which occur considerably in aquatic habitats gives a clue of their major function (Debroas et al., 2017). Grossart and Rojas-Jimenez (2016) pointed out that aquatic fungi are forgotten in microbial ecology in spite of their valuable ecosystem services.

Filamentous fungi are capable of producing several organic acids as well as enzymes to recycle natural and synthetic substrates (Cosgrove et al., 2007). Evolution of peroxidases of fungi (capable to degrade lignin) dates back to 300 million years responsible for carbon cycle in soils (Floudas et al., 2012). Fungi in aquatic habitats are the major saprophytes, mutualists and organic matter recyclers (Gutiérrez et al. 2011). Leaf litter decomposition in lotic ecosystems serves as an authentic indication for the dominance of higher fungi than bacteria in building up of biomass (90-95\% of total microbial biomass) and enzymatic capability of degradation especially in early phases of decomposition (Krauss et al., 2011; Grossart et al., 2019). This notion has been strengthened further by assay of fungal fatty acids by ${ }^{13} \mathrm{C}$ labeling, which resulted in building up of biomass by fungi 10-fold higher than bacteria (Fabian et al., 2017). Similarly, ${ }^{14} \mathrm{C}$ labeled acetate inclusion into ergosterol (filamentous fungal-specific lipid), ${ }^{14} \mathrm{C}$ labeled leucine into DNA and $3 \mathrm{H}$-thymidine into proteins of bacteria revealed that production of fungi highly surpasses bacteria (Krauss et al., 2011). Recent methodology especially detection of marker genes resulted in exploration of unknown fungal diversity in aquatic bodies (Monchy et al., 2011; Richards et al., 2015). In the context of climate change and anthropogenic influence, knowledge on the diversity and ecological functions of fungi in aquatic ecosystems facilitates future sustainable developments. High richness and diversity of filamentous fungi in natural ecosystems symbolize its significant functions at micrometer scale (Boddy, 1999; Talbot et al., 2014). With advances during the last century, tremendous efforts have been invested to understand the structure and complexity of mycobiome especially diversity, biogeography and ecological services in aquatic ecosystems using novel techniques in the new millennium. Mycobiome evaluation has been performed from different angles in freshwaters, marine waters and beyond aquatic habitats with traditional as well as sophisticated techniques. The present review focuses briefly on some advances on the diversity and ecological processes of filamentous fungi in various aquatic habitats in view of meeting the challenges of fungal conservation.

\section{AQUATIC ECOSYSTEMS AND FUNGI}

Unlike soil ecosystems, studies on aquatic fungi in freshwaters (e.g. water columns and sediments) and marine waters (e.g. snow, hydrothermal vents) are inadequate (Tedersoo et al., 2018; Grossart et al., 2019). Earlier notion of lower diversity of fungi in aquatic ecosystems as compared to

*The lifetime achievement award lecture delivered on November 07, 2019 in the $46^{\text {th }}$ Annual Meeting of the Mycological Society of India, Pondicherry University. This contribution has been dedicated to my mentors Prof. K.M. Kaveriappa, Prof. F. Bärlocher and Prof. D.J. Bhat. 
soil ecosystems has been clearly disproved (Grossart et al., 2019). Aquatic ecosystems vary in evolutionary age, spatiotemporal gradient, altitude, depth, organic matter transport, residence time of organic matter and fungal abundance (Grossart et al., 2019). A wide range of natural and artificial aquatic bodies provide ample scope to evaluate mycobiome component and their ecological functions (Box 1). Those fungi in aquatic bodies which are not cultivable are termed "fungal dark matter" and such fungi are highly diverse in several natural lentic bodies in Germany as well as Scandinavia (Giner, 2016; Grossart et al., 2016; Khomich et al., 2017). Many aquatic habitats are hotspots of aquatic fungi, while some habitats are ecologically extreme (e.g. temperature, pressure, nutrients, salinity, burial and water movement) but support numerous aquatic fungi which denotes fungal adaptation. Similar to natural aquatic habitats, quite a lot of artificial aquatic habitats invariably exhibit extreme conditions (e.g. low oxygen, high temperature, heavy metals and radionuclides). Biogas and nuclear reactors also offer unique opportunities to evaluate diverse fungi, their adaptations and functions.

\section{Box 1. Natural and artificial aquatic habitat}

\begin{tabular}{|ll|}
\hline Freshwater & Artificial \\
Snow and glaciers & Small and large reservoirs \\
Rivers & Irrigation canals \\
Waterfalls & Waterfalls \\
Aquifers & Fountains \\
Springs & Temples tanks/ponds \\
Hot water springs & Tanks \\
Lakes & Garden puddles \\
Marshlands & Hydroponic systems \\
Ground waters & Swimming pools \\
Karsts and caves & Street gutters \\
& Street pipelines \\
Marine & Tap waters \\
& Cooling towers \\
Snow and glaciers & Nuclear reactors \\
Estuaries & Mining waters \\
Mangroves & Aquaculture ponds \\
Salt marshes & Wastewater ponds \\
Coastal habitats & Wastewater sewers \\
Open ocean & Livestock waste ponds \\
Deep sea & \\
Hydrothermal vents & \\
\hline
\end{tabular}

Urban locations with human inhabitation resulted in various artificial aquatic habitats (e.g. gutters, waste water/sewage networks, cooling towers and reservoirs) (Grossart et al., 2019). Not much attention has been focused to understand the diversity of fungi in such habitats. Many conidia of aquatic and aeroaquatic hyphomycetes are common in the urban street runoff of southwest India (Ghate and Sridhar, 2018). Semi-blocked habitats (e.g. tap water and washroom pipe lines) also support a number of fungi similar to indoor air (Babič et al., 2016). Similarly, the lentic and semi-lentic habitats in urban regions (e.g. gardens, irrigation lands, aquacultures, natural aquaria, fountains, hydroponic systems and tree holes) provide new avenues to evaluate fungal component, diversity and functions.

Industrial developments resulted in artificial aquatic habitats (e.g. sewage treatment plants, aquaculture systems, livestock rearing/maintenance and mine rejects/dumps). Similarly, many natural habitats consist of dangerous pollutants (e.g. uranium, arsenic, lead and cadmium), which are also of great significance to understand the adaptation or bioremediation potential of inhabiting aquatic fungi. Many natural habitats (lakes, streams, rivers, coastal regions and oceans) are perturbed by human interference by addition of unnatural products or wastes to the highest scale (e.g. plastics, microplastics and polyurethane). Such interference leads to develop artificial or unusual habitats for fungi and how fungi cope with such exotic conditions remain to be answered. Do they acclimatize or adapt or alter their lifestyle suitable to changed environment? What are the upper limits of fungi to cope with unusual habitats? For example, many aquatic hyphomycetes have adapted to heavy metal hyperpolluted aquatic bodies in Mansfeld region in Central Germany (Krauss et al., 2011). Some mechanisms of adaptation of aquatic hyphomycetes to heavy metal stress have been reviewed by Krauss et al. (2011). Solé et al. (2008b) demonstrated how the community of aquatic hyphomycetes serves as bioindicators of anthropogenic stress. Recently, exposure of freshwater fungus Neonectria lugdunensis to mine drainage showed triglycerols, which serve as biomarker in assessment of risks in streams (Seena et al., 2020).

Fungi are capable to occupy and function in more complex niches than expected and some represent in dual niches with different capability (Selosse et al., 2018). Saprotrophy, mutualism, mycorrhizas, endopytism, lichenization and parasitism are the interesting examples of fungal lifestyles. Some multiple niches of fungi (bipartite or tripartite) include: mycorrhizal and endophytic; mycorrhizal and saprophytic; endophytic and parasitic; endophytic and saprophytic; endophytic, saprophytic and parasitic. Similarly, switching their functions (e.g. endophytism to saprophitism to parasitism or reverse; toxigenic to non-toxigenic) seems to be dependent on the changing ecological or climatic/ environmental conditions. Clear understanding of fungal niches, change of fungal lifestyle and exploitation of fungal traits towards benefits are the challenging tasks of mycologists. Niches outside the typical aquatic habitats support aquatic, aero-aquatic and fungal-like organisms (Box 2). Occurrence and perpetuation of aquatic fungi in intermittent and ephemeral streams or rivers have drawn the attention of mycologists recently. Typical freshwater fungi occurring in the streams and rivers were also found in many semi-aquatic habitats outside their usual niches and pose a question that are the freshwater hyphomycetes strictly amphibious? Shearer et al. (2007) have pointed out that

Box 2. Niches outside the aquatic habitats support aquatic fungi

$\begin{array}{ll}\text { Forest floors } & \text { Live leaves/twigs/roots } \\ \text { Stream slopes } & \text { Epiphytes } \\ \text { Dendrotelmata (tree holes) } & \text { Stemflow } \\ \text { Tree canopy } & \text { Throughfall } \\ \text { Crown humus } & \text { Coastal and dunes }\end{array}$


freshwater fungi occur in forest floors of rainforests owing to long moist conditions. Similar observations were made from the forests worldwide and scrub jungles of the southwest coast of India (Sridhar, 2009b; Chauvet et al., 2016). Similar to niches outside the freshwater bodies, many niches outside the marine habitats also harbor typical marine fungi (e.g. coastal sand dunes). Selection of fungi in different aquatic environments, their adaptability to natural or artificial perturbations (long-term or short-term) and effective mechanisms of transport (natural and vector-mediated) across the niches and interlinks needs to be clearly understood. Some of the buffer zones especially estuaries and mangroves consists of mosaic of fungi (terrestrial, marine and freshwater) depending on the wet and dry regimes (Sridhar and Kaveriappa, 1988; Ananda and Sridhar, 2002; Chauvet et al., 2016).

\section{DIVERSITYAND DISTRIBUTION}

Freshwater fungi: Freshwater mycobiome attracted researches to explore the diversity, distribution and biogeography in different parts of the world (Table 1). Goh and Hyde (1996) classified freshwater hyphomycetes into four subgroups: 1) Ingoldian fungi: Consists of fungi growing on leaves and twigs in tree-lined streams, brooks and well-aerated lakes; 2) Aeroaquatic fungi: Fungi usually known from stagnant (ponds and ditches) or slow-running streams capable to grow under semi-aquatic conditions; 3) Terrestrial-aquatic fungi: Conidial fungi thriving in rain drops and on intact plant parts (surfaces of leaves and passing through trunks); 4) Submerged-aquatic fungi: An assemblage of heterogeneous fungi occurring on submerged decaying plant detritus.

Around 335 morphospecies of aquatic hyphomycetes have been reported on broad range of substrates which indicate their wide global distribution (Duarte et al., 2016). However, according to $\mathrm{Hu}$ et al. (2013), 416 species of aquatic hyphomycetes are reported from China (which includes Ingoldian-, aeroaquatic-, submerged- and terrestrialhyphomycetes; freshwater Chytridiomycetes and Zygomycetes). Anamorph-teleomorph connections of freshwater hyphomycetes have reached a total of 77 connections (Sivichai and Jones, 2003; Hu et al., 2014).

Among the geographic temperate regions, Europe is the most studied region in this regard followed by North America, South America and Asia. Relatively South Africa as well as polar regions are poorly studied. Duarte et al. (2016) have plotted the distribution of 335 morphospecies of aquatic hyphomycetes from 15 geographic regions based on 352 diversity surveys to develop a model. The outcome of this model is that at least 29 investigations/region needs to follow $50 \%$ of aquatic hyphomycetes, while 275 investigations/ region are necessary to attain a $90 \%$ target. Amongst the 15 geographic locations evaluated, northern America, tropical (western and eastern) and temperate Europe accounts for 50\% of the target, which reveals the lacuna in evaluation of this group of fungi in the vast geographical regions of the globe. With increasing geographic distance the morphospecies community was correlated negatively, while spore abundance was influenced by natural or human interference. High similarity of aquatic hyphomycetes (among 335 morphospecies) was seen between the distant geographic locations possessing similar climatic conditions, which is supporting the conclusions drawn by Wood-Eggenschwiler and Bärlocher (1985) based on 150 species of aquatic hyphomycetes. It is interesting to note that aquatic hyphomycete community affected at narrow spatial scale (2.9-100 km) (Pascoal et al, 2005; Sole et al., 2008a; Duarte et al., 2009). This again demands the extent of efforts necessary to follow the distribution pattern of aquatic hyphomycetes at global scale.

Freshwater ascomycetous fungi prefer to colonize woody substrates in the aquatic habitats (Shearer and Raja, 2017). Similar to marine ascomycetous fungi, freshwater ascomycetous fungi also possess gelatinous sheaths or appendages for buoyancy. Shearer and Raja (2017) documented up to 675 species of freshwater ascomyceteous fungi globally. From China 256 species have been reported (Hu et al., 2013). Similar to hyphomycetes, ascomycetes show latitudinal gradient and their diversity is highest in the junctions of temperate and tropical regions (Shearer et al., 2015; Raja et al., 2018). Aeroaquatic fungi are known for their helicosporus conidia and trap air bubble to float in water. Besides in typical aquatic habitats, they inhabit moist forest leaf litter, wood, bark and twigs in semi-aquatic habitats. Morphologically they are versatile and spore morphology is

Table 1. Selected recent literature on freshwater mycobiome

- 2000. Fungal diversity in heavy metal polluted waters (Sridhar et al.)

- 2001. Aquatic hyphomycetes in hyperpolluted waters (Krauss et al.)

- 2001. Trichomycetes and Other Fungal Groups (Misra and Horn)*

- 2003. Freshwater Mycology (Tsui and Hyde)*, **

- 2005. The Fungal Community (Dighton et al)*

- 2005. Methods to Study Litter Decomposition (Graça et al.)**

- 2005. Aquatic hyphomycetes in contaminated groundwater wells (Krauss et al.)

- 2006. Genera of Freshwater Fungi (Cai et al.)

- 2007. Fungal biodiversity in aquatic habitats (Shearer et al.)

- 2008. Fungi in a heavy metal precipitating stream (Ehrman et al.)

- 2008a. Improved coverage of fungal diversity in polluted groundwaters (Soléet al.)

- 2008b. Aquatic hyphomycetes as bioindicators of anthropogenic stress (Solé et al.)

- 2008a. Fungal biomass and diversity in heavy metal polluted sediments (Sridhar et al.)

- 2008b. Novel Techniques and Ideas in Mycology (Sridhar et al.)*, **

- 2009a. Frontiers in fungal ecology, diversity and metabolites (Ed. Sridhar)*

- 2009b. Fungi in the tree canopy (Sridhar)

- 2010. Fungi in lake ecosystems (Wurzbacher et al.)

- 2011. Fungi in freshwaters (Krauss et al.)

- 2013. Biodiversity of aquatic fungi in China (Hu et al.)

- 2013. Aquatic hyphomycetes after a red sludge disaster (Vass et al.)

- 2014. Freshwater Fungi and Fungal-Like Organisms (Jones et al.)*

- 2016. Aquatic fungi (Fungal Ecology 19, 1-218) (Ed. Bärlocher)*, **

- 2016. Beyond the water column (Chauvet et al.)

- 2016. Biogeography of aquatic hyphomycetes (Duarte et al.)

- 2016. Aquatic fungi (Grossart and Rojas-Jimenez)

- 2017. Global-scale coordinated networks (Boyero and Pearson)

- 2017. The Fungal Community (Dighton and White)*

- 2017. Ingoldian fungi in Brazil (Fiuza et al.)

- 2017. Diversity and community composition of aquatic ascomycetes (Friggens et al.)

- 2018. Freshwater hyphomycetes from Brazil (Moro et al.)

- 2018. Ground water mycobiome (Nawaz et al.)

- 2018. Water quality on diversity in a tropical river (Ortiz-Vera et al.)

- 2019. Lignicolous freshwater fungi from China and Thailand (Bao et al.)

- 2019. Species-specific quantitative real-time PCR assays (Baudy et al.)

- 2019. Wildfire impacts on freshwater detrital food webs (Carvalho et al.)

- 2019. Stress response and the ecological function of aquatic fungus (Duarte $e t a l$.)

- 2019. Fungi in aquatic ecosystems (Grossart et al.)

- 2019. Fungi in freshwater ecosystems (Lepère et al.)

- 2019a. Biodiversity of litter fungi in streams (Seena et al.)

- 2020. Uranium and leaf-litter decomposition (Bergmann and Graça)

*, Chapters/articles therein; **, Methods therein 
quite helpful in identification. From aquatic and semi-aquatic habitats up to 90 species of aeroaquatic fungal species have been reported (Raja et al., 2018). A recent study revealed occurrence of 71 species (in 14 genera) of aeroaquatic hyphomycetes in mainland China (Zhao et al., 2007). Aquatic hyphomycetes lead their life as endophytes in aquatic as well as terrestrial habitats (Bärlocher 2006; Kohout et al., 2011; Sridhar, 2009b). About 21 species of aquatic hyphomycetes were root endophytes in riparian vegetation in the Western Himalayas, while 18 species were root endophytic in the Central Western Ghats (Arya and Sati, 2011; Ghate and Sridhar, 2017). From China, seven endophytic fungi associated with lichens have been reported (Li et al., 2007). Recently, aquatic lichens have been reported from freshwater habitats (Thüs et al., 2014). Permanently submerged true aquatic lichens are less than 10 species found in temperate regions. Globally, up to 250 species of lichens are confined to freshwater amphibious or sub-aquatic habitats. Forty three species (in 20 genera) of lichens inhabiting in freshwaters of Italian Alps have been documented by Nascimbene and Nimis (2006). Similarly, seven species of freshwater lichenforming fungi have been recorded from Poland (Matura et al., 2017). Freshwater lichens and their zonation in mountain streams have been reported from Poland (Krzewicka et al., 2017). Freshwater lichens thalli being attached to stable structures in aquatic habitats (rocks and logs) also serve as stagnant refuge for survival of hyphomycetes in such locations.

Freshwater bodies have many gradations like location (altitude), depth, availability of water, availability/ nature of carbon sources (organic matter) and minerals (Grossart et al., 2019). Such geographic and abiotic differences leads to selection of suitable fungi those are capable to function under specific conditions. However, those could not function under such conditions may have survival mechanisms. Existence of a fungus in a specific situation and its function are different aspects. Baas-Becking's hypothesis says that "everything is everywhere, but the environment selects" (Bass-Becking, 1934; De Wit and Bouvier, 2006). The characteristic of the aquatic body is supreme in selection of suitable fungi to carry out ecological functions, which has evolved over a period of time. Despite such situation, many chaotic situations upset the normal conditions of the aquatic bodies, which influence the diversity and ecological functions of the inhabiting fungi. Influence of chaotic situation on fungi and its replenishment on recovery to normal situation are the interesting and worth exploring aspects. Several basic and applied concepts pertaining to aquatic fungi have been addressed in an edited volume of the journal Fungal Ecology by Bärlocher (2016).

Marine fungi: Marine mycobiome has been explored to understand the diversity, distribution and biogeography worldwide (Table 2). So far about 1260 species of marine fungi are known worldwide from many substrates as well as marine habitats against an estimate of 10-12 thousand (Jones et al., 2019). About 943 ascomycetes, 213 yeasts (ascomycetous and basidiomycetous), 27 chytrids and 637 endophytic fungi were reported from different marine and marine-influenced habitats (Sakayaroj et al., 2012; Jones et al., 2015). From China, 213 species consisting of 117 ascomycetes, 48 hyphomycetes, 42 yeasts, 5 oomycetes and 1 basidiomycete have been reported (Hu et al., 2013). The substrates available for fungi in marine ecosystems are enormous (e.g. water, variety of woody materials, leaf litter, seaweeds, seagrass, algae, calcareous shells, exoskeletons and sediments). About 190 species are known from marine driftwood and test wood panels, while about 300 species of marine fungi have been reported from decomposing mangrove wood (Raghukumar, 2017). From brown alga Fucus serratus up to 79 species of fungi have been listed by Zuccaro and Mitchell(2005).

From different niches in deep sea (e.g. water, sediments, wood, calcareous shells and hydrozoal chitin) at varied depths (600-10,500 m) Raghukumar and Damare (2008) listed 38 fungi. From hydrothermal vents, methane cold-seep regions and deep sea sediments several filamentous fungi and yeasts have been reported (Jones et al., 2020). Sea foams deposited on the sandy beaches possess many marine fungi. Marine fungi are also endolithic as inhabitants of shells, skeletons and inorganic solid substrates (calcium carbonate and silica). The saline habitats like Red Sea and Baltic Sea open oceans are represented by more of Chytridiomycota than Dikarya (Hassett et al., 2019a). Besides typical marine fungi, marinederived asexual fungi (may be from terrestrial origin) have adapted to marine habitats (driftwood, intertidal wood, sediments, seawater, deep sea, salt marshes and seaweeds) (Pang et al., 2016). Owing to repeated occurrence and isolation, 214 species have been considered as marinederived fungi (Jones et al., 2015). Many fungi exist in marine habitats as endophytes with seaweeds, seagrass, mangrove

Table 2. Selected recent literature on marine mycobiome

- 2000. Marine Mycology (Hyde and Pointing)*, **

- 2002. Fungi in Marine Environments (Hyde) *, **

- 2005. The Fungal Community (Dighton et al.)*

- 2005. Marine mycology (Botanica Marina 48, 329-452) (Ed. Jones)*

- 2007. Marine Fungi of Kerala (Raveendran and Manimohan)

- 2008. Deep-sea fungi (Raghukumar and Damare)

- 2009. Marine fungi from mangroves of Malaysia (Alias and Jones)

- 2009. Classification of marine fungi (Jones et al.)

- 2009a. Frontiers in Fungal Ecology, Diversity and Metabolites (Ed. Sridhar)*

- 2010. Diversity and adaptation of deep-sea fungi (Raghukumar et al.)

- 2011a. Fifty years of marine mycology (Jones)

- 2011. Marine Mangrove Fungi of Taiwan (Pang et al.)

- 2012. Marine Fungi and Fungal-Like Organisms (Jones and Pang)*

- 2012. Biology of Marine Fungi (Raghukumar)* **

2014. Fungi in diverse extreme marine habitats (Raghukumar et al.)

- 2015. Molecular diversity and distribution in Europe (Richards et al.)

- 2016. Aquatic fungi (Grossart and Rojas -Jimenez)

- 2016. Global biogeography of marine fungi (Tisthammer et al.)

- 2017. The Fungal Community (Dighton and White)*

- 2017. Diversity and community of aquatic ascomycetes (Friggens et al.)

- 2017. Fungi in Coastal and Oceanic Marine Ecosystems (Raghukumar)

- 2017. How to boost marine fungal research (Reich and Labes)

- 2017. Marine filamentous fungi (Sridhar)

- 2018. Antarctic cryptoendolithic fungal communities (Coleine et al.)

2019. Fungi in the marine environment: Open questions and problems (Amend et al.)

2019. Fungi in aquatic ecosystems (Grossart et al.)

2019. Diversity of fungi from mangrove sediments (Hal dar and Nazareth)

2019a. Global diversity of planktonic marine fungi (Hassett et al.)

2019b. Arctic marine fungi (Hassett et al.)

2019. An online resource for marine fungi (Jones et al.)

2019. Marine fungi associated with Antarctic macroalgae (Ogaki et al.)

2019. Insights into fungal diversity in hydrothermal vent (Pang et al.)

2019. The diversity and roles of Penicillium in intertidal zones (Park et al.)

2019. Fungi in cold deep seas (Raghukumar)

2019. Characterization of fungal biodiversity and communities (Wainwright et al.)

- 2020. Marpho-molecular characterization of marine fungi (Dayarathne et al.)

2020. Phylogeny of mangroves and deep-sea sediments fungi (Jones et al.)

2020. Cultivable fungi from deep-sea sediments of Antarctica (Ogaki et al.)

Chapters/articles therein; **, Methods therein 
vegetation and salt marshes. About 52 hosts (including mangroves, saltmarsh plants, seagrass and seaweeds) supporting 637 endophytic fungi as reported by Sakayaroj et al. (2012). Many endophytic fungi could not be identified up to species level based on morphological grounds (Venkatachalam et al., 2015). According to Jones (2011b), 6000 species of endophytic fungi exist in marine ecosystem. Endophytic fungal studies in marine and mangrove habitats projected several new species as well as potential of marinederived endophytic fungi. Many marine pathogens on microalgae, cyanobacteria, diatoms, seaweeds, salt marshes, mangroves and animals have also been reported (Jones et al., 2019). Hawksworth (2000) pointed out that there are about 700 species of lichens which exist in coastal rocks and are categorized based on zonation as sublittoral, littoral, supralittoral and terrestrial.

In terrestrial habitats, decline in species richness with increased latitude has been considered as central dogma of global biogeography (Hillebrand, 2004). According to some studies, freshwater hyphomycetes follow this trend by decreased similarity with increased latitude (WoodEggenschwiler and Bärlocher, 1985; Duarte et al., 2016). Does this trend also apply to marine environment? Some eukaryotic microbial species has local/global ratio as high as $80 \%$, which denotes increased dispersible ability with resting spores leading to homogeneity in distribution (Finlay, 2002; Lennon and Jones, 2011). However, the ocean currents may play a major role in wide distribution of marine fungi. Although marine fungi have cosmopolitan distribution, some of the species are restricted to tropical, sub-tropical, temperate and polar regions as well. Endemism in marine fungi is due to endemic substrates or hosts, which needs further investigations. High fungal diversity has been evident from the Atlantic, Indian and Pacific Oceans owing to the occurrence of a wide variety of substrates and mangrove habitats (Schmit and Shearer, 2003; Pang et al., 2011).

Methods of evaluation: Specific focused inventories are necessary to understand the structural (species richness and extent of occurrence) and functional (decomposition and role in food web) diversity of fungi in the aquatic ecosystems. Efforts on conventional inventories in different aquatic ecosystems, isolation of fungi, morphology-based descriptions and deposition of cultures in authentic repositories will greatly strengthen our knowledge on the diversity, ecological relevance and ecosystem services of aquatic fungi. Designing and following newer eco-friendly techniques are the essential steps for aquatic fungal expedition (Graça et al., 2005). More detailed procedures to identify, isolate and maintain cultures of aquatic fungi are available (Gessner et al., 2003; Marvanová, 2005; Descals, $2005,2008)$. Several emerging methods to investigate fungi and their functions in aquatic habitats have been reviewed by Grossart et al. (2019). Box 3 projects common classical, biochemical and molecular techniques employed to study aquatic fungi. Many classical techniques allow quick assessment of aquatic fungi (e.g. foam observation, filtration of water and floatation-adhesion), some techniques needs a bit longer time for assessment (e.g. bubble chamber incubation, conidial trap on rosin/latex and sediment baiting), while damp incubation of detritus (leaf/woody litter) takes more time to allow to produce spores of inhabiting fungi (Ascomycetes and Basidiomycetes). Biochemical techniques help to assess the fungal biomass in aquatic habitats (e.g. ATP, chitin and fatty acids), but some techniques require more time for assessment (e.g. acetate incorporation and monoclonal antibodies). Some biochemical parameters although provide fungal biomass in detritus, it encompass many terrestrial fungi too. With available sequences in the repositories, molecular techniques will provide more precision in phylogeny. However, more efforts are needed to deposit the specific fungal sequences in the repositories in view of the requirement for more precision in future studies. Another important advantage of molecular techniques is exploration of non-culturable, non-sporulating and cryptic fungi (rare and with low biomass) in aquatic ecosystems. Use of simple inexpensive classical techniques to distinguish and score conidia in different substrates before stepping into molecular approaches is an essential footstep. These classical methods are quite helpful in understanding the impact of climate change on aquatic fungi in many aquatic habitats.

Besides laboratory studies, laboratory microcosm experiments and small ecological niches having extreme conditions (e.g. salinity, temperature, organic load and pollutants) serve as ideal locations to carry out mesocosm experiments to understand the fungal community ecology as

\section{Box 3. Techniques to study aquatic fungi}

Classical techniques
Foam observation
Membrane filtration of water
Baiting (pollen, leaf litter and wood)
Baiting with sediment
Damp incubation (leaf litter or wood)
Bubble chamber incubation
Floatation-adhesion of conidia
Conidial trap on rosin/latex
England Finder to locate conidia
Single spore isolation and culture
Spore viability by tetrazolium chloride
Preservation in deionized water/ paraffin oil/ liquid nitrogen
Biochemical and molecular techniques
ATP
Chitin
Ergosterol
Fatty acids
Enzymes
Glucosamine
Aectate incorporation
Monoclonal antibodies
Fluorescence $i n$ situ
hybridiation
T-RFLP
DGGE/TGGE
ITS
Nested PCR
PRNA
Pyrobe-based qPCR
Metagenomics
Redundancy analysis


well as their bioconversion potential (Zingel et al., 2018; Stibor et al., 2019). Many experiments are necessary to be conducted under the field conditions (baiting in water and sediment) in view of fungal activity in fairly pristine and polluted aquatic habitats. To follow the biogeography, extrapolate the global diversity and functions of aquatic fungi, it is necessary to depend on global networks to access different aquatic ecological niches. To achieve an uniformity, substrate to be baited for assay should be commonly available and decomposable like cotton strip will be quite ideal (Jabiol etal., 2020).

\section{ECOLOGICAL FUNCTIONS}

Freshwater fungi: Freshwater habitats consist of several saprophytic, planktonic, endophytic, pathogenic and parasitic fungi. The substrates support such fungi in freshwaters include dead (leaf litter, flowers, fruits, twigs, bark and logs) and live (riparian roots, macrophytes, bryophytes, ferns, algal mats and lichens) organic matter. Depending on the type and longevity of substrates, aquatic fungi transform the coarse particulate organic matter (CPOM) into fine particulate organic matter (FPOM). Freshwater hyphomycetes are well known for their role in transforming CPOM into FPOM through their enzyme systems to gear up the food web (Suberkropp and Klug, 1980), but such studies are meager in lakes, rivers and oceans (Crowther and Grossart, 2015). It is known that freshwater hyphomycetes in streams lower the $\mathrm{C}: \mathrm{N}: \mathrm{P}$ ratio to enhance their palatability to invertebrates (Krauss et al., 2011). The diversity and role of filamentous fungi in food webs in pelagic zone is also not clearly understood (Jobard et al., 2010). Fungi have the capacity to enhance the organic matter palatable to grazing macrozoobenthos in lakes (Crowther and Grossart, 2015; Attermeyer et al., 2013). Decomposition of autochthonous and allochthonous CPOM in freshwaters is possible by fungal enzymes and shredders leading to pools of FPOM, dissolved organic matter (DOM), minerals and metabolites. Such transformations lead to produce processed organic matter with increased fungal biomass which serves as a palatable nutritious source to detritivores and other aquatic fauna (e.g. prawns and fishes). Part of the fungal biomass is transformed into conidia and dispersed swiftly in aquatic bodies to catch up new substrates, however, some fungal biomass will be retained on the substrate to develop perfect states (Bärlocher, 2009). To escape from shredders and from unidirectional flow in lotic ecosystem, aquatic fungi colonize stable detritus, live roots/macrophytes (as endophytes) and have developed strategies to survive under semi-aquatic and dry regimes (Chauvet et al., 2016; Sridhar, 2019).

Marine fungi: Marine food web depends on input of organic matter from terrestrial, mangroves, salt marshes, coral reefs, seaweeds, sea grass and animal substrates. Marine filamentous fungi being well equipped with enzymes, transform organic matter leading to the development of habitats for colonization of other marine organisms. Besides, transformation of recalcitrant organic matter into nutrient rich foodstuff along with fungal biomass meets nutritional requirements of several marine fauna leading to gear up the food web. Such biotransformation processes differ between geographic regions as well as in ecosystems. Mangroves, salt marshes and coral reefs are quite helpful to study the fungalfaunal interactions and mechanisms of energy flow. Mangroves attract a variety of fauna (crabs, snails, birds, insects and bats) owing to their rich detritus source. These fauna generate substantial quantities of organic matter (feces and guano). Caterpillars of the moth (Hyblea purea) in the Caeté estuary in Brazil is reported to ingest heavy quantities of leaf biomass of mangrove leaves (Avicennia germinans) in a few weeks and generate a huge fecal mass along with leaf particles (Koch and Wolff, 2002). Bats as well as birds also accumulate substantial guano in the Man-of-War Cay (Belize), while the Teredo bratschi (shipworm borer) generate feces by wood boring (Kohlmeyer et al., 1995). The process of organic matter input, dynamics of food web and productivity may vary in different habitats and offers excellent opportunity to explore connections and interaction of flora, fauna and fungi. However, the role of fungi in pelagic as well as benthic food webs is not precisely understood (Jobard etal., 2010; Dethier, 2014).

Human interference: Natural habitat destruction or alteration is the most threatening human interference against aquatic fungi. Destruction of riparian habitats and watercourse modification in lotic habitats limit input of organic matter and its duration of retention (Tolkkinen et al., 2020). Similar to soil and air pollution, several anthropogenic pollutants have access to the aquatic ecosystem and these directly influence the diversity and functions of aquatic fungi. Some of the influences of human interferences on the aquatic fungi in the aquatic ecosystems are listed in Box 4. Krauss et al. (2011) discussed the impacts of human interference such as altered riparian vegetation, $\mathrm{pH}$, alkalinity, metal pollution, eutrophication, temperature and climatic change on aquatic hyphomycetes. Xenobiotics in the aquatic ecosystems influence the fungi on their growth, sporulation and detritus processing. However, aquatic fungi possess capabilities to metabolize a wide variety of xenobiotics and are known to play an important role in natural bioremediation (Krauss et

\section{Box 4. Human interferences influence aquatic fungi}

Alteration of riparian zone

Channeling/removal of obstructions

Biomass removal

Dredging and sand mining

Building seawall

Exotic tree species

Agriculture and mariculture

Thermal pollution

Mine refuse

Impact of fire

Sewage

Hospital wastes

Industrial effluents

Agricultural fertilizers

Plastics and microplastics

Pesticides

Xenobiotics

Heavy metals

Nanoparticles

Radionuclides 
al., 2011; Grossart and Rojas-Jimenez, 2016). Krauss et al. (2011) has given a schematic representation of biochemical responses and adaptation of aquatic hyphomycetes under heavy metal stress in Central Germany. Aquatic hyphomycetes are also known for biosorption and bioaccumulation of heavy metals (Krauss et al., 2003; Jaeckel et al., 2005). All such traits of aquatic fungi are important for the removal of heavy metals from aquatic bodies. Series of experiments have been performed in heavy metal polluted streams of Central Germany to study the stress responses and adaptability of aquatic hyphomycetes (Krauss et al., 2008). Schlosser et al. (2008) reviewed the responses of aquatic hyphomycetes to organic pollutants. Understanding the metabolic potential of aquatic fungi to tolerate, adapt, degrade xenobiotics and continue detritus decomposition in aquatic ecosystem provides more insight about future bioremediation tasks. However, leaf litter decomposition as one of the major ecological functions of aquatic hyphomycetes will be retarded in the presence of pollutants in the aquatic habitats (Krauss et al., 2011; Seena et al., 2019b). Among the pollutants, plastics seem to be most prevalent in freshwaters as well as in marine environments. Colonization and degradation of plastic debris in marine ecosystems by fungi has been discussed by Jacquin et al. (2019). Aquatic fungi serve as authentic bioindicators in natural ecosystem as well as microcosms in the laboratories owing to their metabolic capabilities and extent of tolerance of heavy metals and xenobiotics (Solé et al., 2008a; Masigol et al., 2019). Wildfire runoffs into streams have been reported to result in the retardation or abandonment of several ecological functions especially leaf litter decomposition along with decrease in the microbial community and invertebrate shredders (Carvalho et al., 2019).

\section{THE INDIAN SUBCONTINENT}

Geographically and climatically the Indian subcontinent $\left(66^{\circ}-98^{\circ} \mathrm{E}, 8^{\circ}-36^{\circ} \mathrm{N}\right)$ has a strategic position in the globe. It possesses an area of $3.3 \mathrm{~m} \mathrm{~km}^{2}$ with $100 \mathrm{~m}$ ha of mountains, 30 $\mathrm{m}$ ha of arid zones and about $8,000 \mathrm{~km}$ coastline (Singh and Chaturvedi, 2017). Ten biogeographic zones possess several ecoregions which are unique and represent aquatic, soil, forest, grassland, mountains and desert ecosystems. The geographic and climatic diversity ranges from the tropical to arctic with mountains, plains and wetlands as major ecosystems. It encompasses $24.2 \%$ forest cover, inland waters (14 major and 44 medium rivers with several tributaries; $0.72 \mathrm{~m}$ ha natural lakes; $3.15 \mathrm{~m}$ ha reservoirs; 1.5 $\mathrm{m}$ ha seasonal shallow waters), coastal wetlands ( $8 \mathrm{~m}$ ha mangroves, estuaries and coast) and coral reefs (about 2,400 $\mathrm{km}^{2}$ ). Total wetlands of India consist of $15.3 \mathrm{~m}$ ha in $4.7 \%$ of total geographic area covering inland $(69 \%)$, coastal $(27 \%)$ and other (4\%) wetlands (SAC, 2011; Bassi et al., 2014). Natural coastal wetlands possess the largest area (663 ha). The total number of wetlands are highest in Bihar (21998) and least in Mizoram (234), while area-wise, these are highest in Gujarat (17.5\%) and least in Mizoram (0.7\%). Ramsar Convention has been proposed so as to protect as many as 26 wetlands in India (WTO, 2012). International treaty of Ramsar Convention on Wetlands in 1971 defines wetlands as "areas of marsh, fen, peat land or water, whether natural or artificial, permanent or temporary, with water that is static or flowing, fresh, brackish or salt, including areas of marine water the depth of which at low tide does not exceed six meters". Accordingly, the Asia consists of 289 Ramsar wetland sites, while Indian subcontinent consists of 27 sites $\left(11,121 \mathrm{~km}^{2}\right) \quad$ (http://wiienvis.nic.in/Database/ramsar wetland sites 8224.aspx; WTO, 2012). Under the Ramsar wetlands, Sunderban wetlands in West Bengal consist of the highest area $\left(4230 \mathrm{~km}^{2}\right)$ followed by Vembanad Kol wetland in Kerala $\left(1513 \mathrm{~km}^{2}\right)$ and Chilka Lake in Orissa $\left(1165 \mathrm{~km}^{2}\right)$. Traditionally, some shrines (e.g. temples) preserve water bodies (tanks or ponds) in their vicinity and fungal diversity of such habitats are unknown. Although 10 biogeographic regions of the Indian subcontinent represent some marine habitats (costal region and islands: Andaman, Nicobar and Lakshadweep), other habitats especially coral reefs and deep seas are not included. The Indian coast has diverse ecosystems, namely mudflats, beaches, shoal, coral reefs, mangroves, salt marshes, lagoons, backwaters, send dunes, salt-prone areas and salt pans. Total mangrove area of the Indian subcontinent is equivalent to $45.8 \%$ of mangroves of South Asia and 3.3\% of world mangroves. Up to $80 \%$ of the total mangroves are housed in the Bay of Bengal (deltaic), while the Arabian Sea possess only about 20\% (estuarine). The recent statistics reveals that highest area of mangroves in India exists in the West Bengal $\left(2114 \mathrm{~km}^{2}\right)$ followed by Gujarat $\left(1140 \mathrm{~km}^{2}\right)$, Andaman and Nicobar $\left(617 \mathrm{~km}^{2}\right)$, Andhra Pradesh $\left(404 \mathrm{~km}^{2}\right)$, Maharashtra $\left(304 \mathrm{~km}^{2}\right)$ and Orissa (243 $\mathrm{km}^{2}$ ) (Mukherji et al., 2019). The coral reefs support several mutualistic fungi in association with seaweeds, seagrass and fauna. About $2375 \mathrm{~km}^{2}$ area of coral reefs exist in India (Venkataraman, 2011). Fringing coral reefs are present especially in the coast of Gujarat, Maharashtra, Goa, Karnataka and Tamil Nadu (Gulf of Mannar and Palk Bay). Besides, Andaman and Nicobar Islands possess large fringing coral reefs, while Lakshadweep Islands consist of Atoll reefs. Small islands adjacent to mainland, intertidal coastal belts, lagoons, solar salterns, coral reefs, Indian Ocean and deep sea are the important ecosystems which support varied fungi.

\section{CONCLUDING REMARKS}

Aquatic resources are important in human welfare especially food security, agriculture, recreation and transport. Attention towards the study of fungal associations have been focused in many habitats (rumens, rice lands and soils), but little attention has been given to aquatic habitats (Grossart et al., 2019). Compared to the soil ecosystems, fungal resources of the aquatic ecosystems are fairly neglected, however, investigations on aquatic mycobiome have the history of more than a century (Bärlocher, 1992; Meyers, 1996). Fungi being important component of earth mycobiome in structuring communities of flora and fauna, their functional role in aquatic habitats have direct relation with aquatic flora as well as fauna (Peay et al., 2016). Successful function of fungi in various ecosystems is possible owing to combination of their unique morphological and biochemical features. Structural and functional assessment of mycobiome in natural and artificial aquatic ecosystems provide valuable information on their role 
in decomposition of organic matter, linking the aquatic food webs, mediate biogeochemical cycles and their potential role in global carbon budget. Polluted artificial ecosystems are repository of pollution-tolerant fungi, which are quite useful in bioremediation. Fungal assemblages in aquatic ecosystems seem to be well organized to cope with positive and negative impacts. Some of the core-group fungi in aquatic habitats may serve as keystone species and their involvement in bioconversion seems to be crucial to gear up the aquatic food web. Similar to plankton trophic switches, fungi in aquatic habitats serve as trophic switches in detritus processing, food web and energy flow (Stibor et al., 2019). Rare and cryptic fungal species (having low competitive abilities) are also important if the functions of keystone or core-group species are impaired(Calatayud et al., 2020).

Single investigation of perennial grass (Phragmites australis) resulted in detection of more than 600 species of fungi (Gessner and Van Ryckegem, 2003), indicating the extent of fungal diversity on the substrate as well as the habitat. Similar to filamentous fungi, stramenopiles (fungal-like organisms) are the major component of aquatic mycobiome, which has several roles in the aquatic habitats. In addition to their capability to degrade recalcitrant substrates, they check the uncontrolled expansion of diatoms, dinoflagellates, phytoplankton, zooplankton, fungi and fungal-like organisms in aquatic ecosystems (Grossart et al., 2019). Role of fungi as an important segment in structuring aquatic food webs similar to plankton in different natural habitats is yet to be clearly understood (Wurzbacher et al., 2010). Another area of interest is the development of mycoviruses (against endophytic and pathogenic fungi), which may tilt the mutualistic association with their host species (Herrero et al., 2009; Nerva et al., 2016).

Several aspects of mycobiome studies could be operated with fairly inexpensive morphological approaches, which enhances our basic knowledge and pave way to focus towards advanced molecular techniques for more precision. Owing to paucity of rDNA locus, nearly $50 \%$ of described marine fungi do not exist in public databases, thus, it is inevitable to depend on morphology-based diversity of marine fungi (Hassett et al., 2019a). Many questions need to be addressed to understand the diversity and role of unknown fungi (and inhabitants of terrestrial fungi) in aquatic habitats. Some fungi also overlap in different aquatic habitats, for example, estuaries, mangroves and coastal regions may provide more information about the intermixing or overlapping fungi, their adaptations and specific functions. These fungi are dependent on specific habitats and substrates under normal conditions. If they are out of place with different substrate, how do they cope with the new situation? Aquatic fungi are also known from the subsurface habitats (aquifers, karsts and caves), what are their role in subsurface biogeosphere? These are important questions for which we need to find answers.

Industrial developments have severe impacts on the aquatic fungi, thus needs specific monitoring not to disturb ecological services of aquatic fungi. Understanding the diversity, dimensions and dynamic role of mycobiome in aquatic ecosystem help updating our knowledge and forecast the danger of catastrophic events due to anthropocene. Aquatic mycobiome provides ample opportunities to understand the basic and applied aspects of mycology in aquatic ecosystems. Knowledge on so-called less-known or untapped habitats provides opportunities for biotechnological and economic innovations (e.g. highly adaptive fungi to harsh/extreme conditions). With the classical and modern techniques, it is challenging to follow the diversity, growth, metabolic potential and decomposition ability of fungi in the earth's largest ecosystem. Our understanding of the diversity and ecological functions will be further improved by traditional approaches of evaluation of ecosystems along with sequencebased approaches. Molecular approaches revealed greater richness, diversity and ecological functions of aquatic mycobiome than previously known. Knowledge on aquatic fungal dimensions, diversity and ecological functions besides an academic exercise it has major implications on ecosystem services like restoration of aquatic bodies and human welfare. The task of understanding the dynamics of aquatic mycobiome warrants inter- and trans-disciplinary interactions through regional and global networks.

\section{ACKNOWLEDGEMENTS}

I am grateful to the Mycological Society of India for conferring the lifetime achievement award. I acknowledge my doctoral students who carried out research on different aspects of aquatic fungi in the Western Ghats and west coast of India. I am thankful to Prof. F. Bärlocher, Canada; G.-J. Krauss and G. Krauss, Germany; F. Cássio and C. Pascoal, Portugal for their collaboration on various aspects of aquatic mycology. I am indebted to the Mangalore University for constant support to carry out research on aquatic mycology. I appreciate the editors and reviewers of $K A V A K A$ for meticulous refereeing the draft of this manuscript.

\section{REFERENCES}

Alias, S.A. and Jones, E.B.G. 2009. Marine Fungi from Mangroves of Malaysia. Institute of Ocean and Earth Sciences, University of Malaya.

Amend, A., Burgaud, G., Cunliffe, M. et al. 2019. Fungi in the marine environment: Open questions and unsolved problems. Ecol. Evol. Sci. 10: e01189-18.

Ananda, K. and Sridhar, K.R. 2002. Diversity of endophytic fungi in the roots of mangrove species on the west coast of India. Can. J. Microbiol. 48: 871-878.

Arya, P. and Sati, S.C. 2011. Evaluation of endophytic hyphomycetes for their antagonistic activity against pathogenic bacteria. Int. J. Microbiol. 2: 343-347.

Attermeyer, K., Premke, K., Hornick, T. et al. 2013. Ecosystem-level studies of terrestrial carbon reveal contrasting bacterial metabolism in different aquatic habitats. Ecology 94: 2754-2766.

Babič, M.N., Zalar, P., Ženko, B. et al. 2016. Yeasts and yeastlike fungi in tap water and groundwater, and their transmission to household appliances. Fungal Ecol. 20:30-39.

Bao, D.F., Su, H.Y., Maharachchikumbura, S.S.N. et al. 2019. Lignicolous freshwater fungi from China and 
Thailand: Multi-gene phylogeny reveals new species and new records in Lophiostomataceae. Mycosphere 10: 1080-1099.

Bärlocher, F. 1992. Research on aquatic hyphomycetes: Historical background and overview. In: The Ecology of Aquatic Hyphomycetes (Ed.: Bärlocher, F.). Springer-Verlag, Berlin, 1-15.

Bärlocher, F. 2006. Fungal endophytes in submerged roots. In: Microbial Root Endophytes. (Eds.: Schulz, B., Boyle, C. and Sieber, T.). Springer, Berlin, 179-190.

Bärlocher, F. 2009. Reproduction and dispersal in aquatic hyphomycetes. Mycoscience 50: 3-8.

Bärlocher, F. 2016. Aquatic fungal ecology. Fungal Ecol. 19: $1-4$.

Bass-Becking, L.G.M. 1934. Giobiologie of Inleiding Tot de Milieukunde (in Dutch). W.P. Van Stockum \& Zoon, The Hague.

Bassi, N., Kumar, M.D., Sharma, A. and Pardha-Saradhi, P. 2014. Status of wetlands in India: A review of extent, ecosystem benefits, threats and management strategies. J. Hydrol. Reg. Stud. 2: 1-19.

Baudy, R., Zubrod, J.P., Röder, N. et al. 2019. A glance into the black box: Novel species-specific quantitative real-time PCR assays to dientangle aquatic hyphomycete community composition. Fungal Ecol. 42: 100858.

Bergmann, M. and Graça, M.A.S. 2020. Uranium affects growth, sporulation, biomass and leaf-litter decomposition by aquatic hyphomycetes. Limnetica 39: $141-154$.

Boddy, L. 1999. Saprotrophic cord-forming fungi: meeting the challenge of heterogeneous environments. Mycologia 91: 13-32.

Boyero, L. and Pearson, R.G. 2017. Global-scale coordinated networks as a tool for exploring the functioning of stream ecosystems. Limnetica 36: 557-565.

Cai, L., Hyde, K.D. and Tsui, C.K.M. 2006. Genera of Freshwater Fungi. Fungal Diversity Research Series \#18, Fungal Diversity Press, Hong Kong.

Calatayud, J., Andivia, E. and Escudero, A. 2020. Positive associations among rare species and their persistence in ecological assemblages. Nat. Ecol. Evol. 4: 40-45.

Carvalho, F., Pradhan, A., Abrantes, N. et al. 2019. Wildfire impacts on freshwater detrital food webs depend on runoff load, exposure time and burnt forest type. Sci. Tot. Environ. 692: 691-700.

Chauvet, E., Cornut, J., Sridhar, K. R. et al. 2016. Beyond the water column: Aquatic hyphomycetes outside their preferred habitat. Fungal Ecol. 19: 112-127.

Coleine, C., Stajich, J.E., Zucconi, L. et al. 2018. Antarctic Cryptoendolithic Fungal Communities Are Highly
Adapted and Dominated by Lecanoromycetes and Dothideomycetes. Front. Microbiol.9: Article 1392.

Cosgrove, L., McGeechan, P.L., Robson, G.D. and Handley, P.S. 2007. Fungal communities associated with degradation of polyester polyurethane in soil. Appl. Environ. Microbiol. 73: 5817-5824.

Crowther, T.W. and Grossart, H.-P. 2015. The role of bottomup and top-down interaction in determining microbial and fungal diversity function. In: Trophic Ecology: Bottom-Up and Top-Down Interactions Across Aquatic and Terrestrial Systems (Eds.: Hanley, T.C. and La Pierre, K.J.). Cambridge University Press, Cambridge, 260-287.

Dayarathne, M.C., Jones, E.B.G., Maharachchikumbura, S.S.N. et al. 2020. Morpho-molecular characterization of microfungi associated with marine based habitats. Mycosphere 11: 1-188.

De Wit, R. and Bouvier, T. 2006. 'Everything is everywhere, but, the environment selects'; what did Baas Becking and Beijerinck really say? Environ. Microbiol. 8: 755-758.

Debroas, D., Domaizon, I., Humbert, J.F. et al. 2017. Overview of freshwater microbial eukaryotes diversity: a first analysis of publicly available metabarcoding data. FEMS Microbiol. Ecol. 93: 10.1093/femsec/fix023

Descals, E. 2005. Techniques for handling Ingoldian fungi. Methods to Study Litter Decomposition. (Eds.: Graça, M.A.S., Bärlocher, F. and Gessner, M.O.). Springer, Dordrecht, the Netherlands, 129-141.

Descals, E. 2008. Procedures for the identification of Ingoldian fungi. In: Novel Techniques and Ideas in Mycology (Eds.: Sridhar, K.R., Bärlocher, F. and Hyde, K.D.). Fungal Diversity Research Series \# 20, Fungal Diversity Press, Yunnan, 215-259.

Dethier, M.N. 2014. Degrading detritus: Changes in food quality of aging kelp tissue varies with species. $J$. Exp. Mar. Biol. Ecol. 460: 72-79.

Dighton, J. and White, J.F. 2017. The Fungal Community: Its Organization and Role in the Ecosystem. Fourth Edition, CRC Press, Taylor \& Francis, Boca Raton.

Dighton, J., White, J.F. and Oudemans, P. 2005. The Fungal Community: Its Organization and Role in the Ecosystem. Third Edition, CRC Press, Taylor \& Francis, Boca Raton.

Duarte, S., Antunes, B., Trabulo, J. et al. 2019. Intraspecific diversity affects stress response and the ecological performance of a cosmopolitan aquatic fungus. Fungal Ecol. 41: 218-223.

Duarte, S., Bärlocher, F., Pascoal, C. and Cássio, F. 2016. Biogeography of aquatic hyphomycetes: Current knowledge and future perspectives. Fungal Ecology 19: 169-181. 
Duarte, S., Pascoal, C., Cássio, F. et al. 2009. Microbial decomposer communities are mainly structured by trophic status in circumneutral and alkaline Streams. Appl. Environ. Microbiol.75: 6211-6221.

Ehrman, J.M., Bärlocher, F., Wennrich, R. et al. 2008. Fungi in a heavy metal precipitating stream in the Mansfeld mining district, Germany. Sci. Tot. Environ. 389: 486-496.

Fabian, J., Zlatanovic, S., Mutz, M. and Premke, K. 2017. Fungal-bacterial dynamics and their contribution to terrigenous carbon turnover in relation to organic matter quality. ISME Journal 11: 415-425.

Finlay, B. 2002. Global dispersal of free-living microbial eukaryote species. Science 296: 1061-1063.

Fiuza, P., Cantillo-Pérrez, T. and Gulis, V. 2017. Ingoldian fungi of Brazil: Some new records and a review including a checklist and a key. Phytotaxa 306: 171200.

Floudas, D., Binder, M., Riley, R. et al. 2012. The Paleozoic origin of enzymatic lignin decomposition reconstructed from 31 fungal genomes. Science 336: 1715-1719.

Friggens, N.L., Taylor, J.E. and Koukol, O. 2017. Diversity and community composition of aquatic ascomycetes varies between freshwater, estuarine and marine habitats in western Scotland. Mycosphere 8: 1267 1287.

Gessner, M.O. and Van Ryckegem, G. 2003. Water fungi as decomposers in freshwater ecosystems. Encyclopedia of Environmental Microbiology, Wiley, New York: https://www.dora.lib4ri.ch/ eawag/islandora/object/eawag:11316

Gessner, M.O., Bärlocher, F. and Chauvet, E. 2003. Qualitative and quantitative analysis of aquatic hyphomycetes in streams. In: Freshwater Mycology (Eds. Tsui, C.K.M. and Hyde, K.D.). Fungal Diversity Research Series \# 10, Fungal Diversity Press, Hong Kong, 127-157.

Ghate, S.D. and Sridhar, K.R. 2017. Endophytic aquatic hyphomycetes in roots of riparian tree species of two Western Ghat streams. Symbiosis 71:233-240.

Ghate, S.D. and Sridhar, K.R. 2018. Aquatic and aeroaquatic fungal spores in urban runoff of southwest India. KAVAKA - Trans. Mycol. Soc. India 5: 23-29.

Giner, C.R., Forn, I., Romac, S. et al. 2016. Environmental sequencing provides reasonable estimates of the relative abundance of specific picoeukaryotes. Appl. Environ. Microbiol. 82: 4757-4766.

Goh, T.K. and Hyde, K.D. 1996. Biodiversity of freshwater fungi. J. Ind. Microbiol. 17: 328-345.

Graça, M.A.S., Bärlocher, F. and Gessner, M.O. 2005. Methods to Study Litter Decomposition - A Practical Guide. Springer, Netherlands.
Grossart, H.-P. and Rojas-Jimenez, K. 2016. Aquatic fungi: Targeting the forgotten in microbial ecology. Curr. Opin. Microbiol.31: 140-145.

Grossart, H.-P., Van den Wyngaert, S., Kagami, M. et al. 2019. Fungi in aquatic ecosystems. Nat. Rev. Microbiol. 17, 339-354.

Grossart, H.-P., Wurzbacher, C., James, T.Y. and Kagami, M. 2016. Discovery of dark matter fungi in aquatic ecosystems demands a reappraisal of the phylogeny and ecology of zoosporic fungi. Fungal Ecol. 19: 28-38.

Gutiérrez, M.H., Pantoja, S., Tejos, E. and Quiñones, R.A. 2011. The role of fungi in processing marine organic matter in the upwelling ecosystem off Chile. Mar. Biol. 158:205-219.

Haldar, S. and Nazareth, S.W. 2019. Diversity of fungi from mangrove sediments of Goa, India, obtained by metagenomic analysis using Illumina sequencing. 3 Biotech 9: 164: https://doi.org/10.1007/s13205019-1698-4

Hassett, B.T., Borrego, E.J., Vonnahme, T.R. et al. 2019b. Arctic marine fungi: biomass, functional genes, and putative ecological roles. ISME Journal: 13: 14841496.

Hassett, B.T., Vonnahmea, T.R., Peng, K.-L. et al. 2019a. Global diversity and geography of planktonic marine fungi. Bot. Mar.: https://doi.org/10.1515/ bot-2018-0113.

Hawksworth, D.L. 2000. Freshwater and marine lichenforming fungi. In: Aquatic Mycology Across the Millennium (Eds.: Hyde, K.D., Ho, W.H. and Pointing, S.B.). Fungal Divers. 5: 1-7.

Herrero, N., Sánchez Márquez, S. and Zabalgogeazcoa, I. 2009. Mycoviruses are common among different species of endophytic fungi of grasses. Arch. Virol. 154: 32-330.

Hillebrand, H. 2004. On the generality of the latitudinal diversity gradient. Am. Nat. 163: 192-211.

Hu, D.-M., Cai, L., Jones, E.B.G. et al. 2014. Taxonomy of filamentous asexual fungi from freshwater habitats, links to sexual morphs and their phylogeny. In: Freshwater fungi and Fungal-Like Organisms (Eds.: Jones, E.B.G., Hyde, K.D. and Pang, K.-L.). Walter de Gruyter GmbH \& Co. KG, Germany, 109131.

Hu, D.-M., Liu, F. and Cai, L. 2013. Biodiversity of aquatic fungi in China. Mycology 4: 125-168.

Hyde, K.D. 2002. Fungi in Marine Environments. Fungal Diversity Research Series \# 7, Fungal Diversity Press, Hong Kong.

Hyde, K.D. and Pointing, S.B. 2000. Marine Mycology - A Practical Approach. Fungal Diversity Research Series \# 1, Fungal Diversity Press, Hong Kong. 
Jabiol, J.J., Colas, F. and Guérold, F. 2020. Cotton-strip assays: Let's move on to eco-friendly biomonitoring! Wat. Res. 170: 115295: https:/doi. Or/10.1016/j.watres.2019.115295

Jacquin, J., Cheng, J., Odobel, C. et al. 2019. Microbial Ecotoxicology of marine plastic debris: A review on colonization and biodegradation by the "Plastisphere". Front. Microbiol. 10: 865, 10.3389/fmicb.2019.00865

Jaeckel, P., Krauss, G.-J. and Krauss, G. 2005. Cadmium and zinc response of the fungi Heliscus lugdunensis and Verticillium cf. alboatrum isolated from highly polluted water. Sci. Tot. Environ. 346: 274-279.

Jobard, M., Rasconi, S. and Sime-Ngando, T. 2010. Diversity and functions of microscopic fungi: a missing component in pelagic food webs. Aquat. Sci. 72: 255-268.

Johnson, T. and F.K. Sparrow. 1961. Fungi in Oceans and Estuaries. J. Cramer, Germany.

Jones E.B.G. 2005. Marine mycology. Bot. Mar. 48: 331-452.

Jones E.B.G., Hyde KD and Pang KL. 2014. Freshwater Fungi and Fungal-Like Organisms. Walter de Gruyter GmbH \& Co KG, Germany.

Jones, E.B.G. 2011a. Fifty years of marine mycology. Fungal Divers. 50: 73-112.

Jones, E.B.G. 2011b. Are there more marine fungi to be described? Bot. Mar. 54:343-354.

Jones, E.B.G. and Pang, K.-L. 2012. Marine Fungi and Fungal-Like Organisms. Walter de Gruyter GmbH \& Co KG, Germany.

Jones, E.B.G., Devadatha, B., Abdel-Wahab, M. et al. 2020. Phylogeny of new marine Dothideomycetes and Sordariomycetes from mangroves and deep-sea sediments. Bot. Mar., 63: 155-181.

Jones, E.B.G., Pang, K.-L., Abdel-Wahab, M.A. et al. 2019. An online resource for marine fungi. Fungal Divers. 96: 347-433.

Jones, E.B.G., Sakayaroj, J., Suetrong, S. et al. 2009. Classification of marine Ascomycota, anamorphic taxa and Basidiomycota. Fungal Divers. 35: 1-187.

Jones, E.B.G., Suetrong, S., Bahkali, A.H. et al. 2015. Classification of marine Ascomycota, Basidiomycota, Blastocladiomycota and Chytridiomycota. Fungal Divers. 73: 1-72.

Khomich, M., Davey, M. L., Kauserud, H. et al. 2017. Fungal communities in Scandinavian lakes along a longitudinal gradient. Fungal Ecol. 27: 36-46.

Koch, V. and Wolff, M. 2002. Energy budget and ecological role of mangrove epibenthos in the Caeté estuary, North Brazil. Mar. Ecol. Prog. Ser. 228: 119-130.

Kohlmeyer, J. and Bebout, B. and Volkmann-Kohlmeyer, B. 1995. Decomposition of mangrove wood by marine fungi and Teredinids in Belize. PSZNIMar. Ecol. 16: 27-39.

Kohout, P., Sýkorová, Z., Čtvrtliková, M. et al. 2011. Surprising spectra of root-associated fungi in submerged aquatic plants. FEMS Microbiol. Ecol. 80: $216-235$.

Krauss, G., Bärlocher, F. and Krauss, G.-J. 2003. Effects of pollution on aquatic hyphomycetes. In: Freshwater Mycology (Eds.: Tsui, C.K.M. and Hyde, K.D.). Fungal Diversity Research Series \# 10, Fungal Diversity Press, Hong Kong, 211-230.

Krauss, G., Bärlocher, F., Schreck, P. et al. 2001. Aquatic hyphomycetes occur in hyperpolluted waters in Central Germany. Nova Hedwigia 72: 419-429.

Krauss, G., Sridhar, K.R. and Bärlocher, F. 2005. Aquatic hyphomycetes and leaf decomposition in contaminated groundwater wells in Central Germany. Arch. Hydrobiol. 162: 417-428.

Krauss, G.-J., Solé, M., Krauss, G. et al. 2011. Fungi in fresh waters: Ecology, physiology and biochemical potential. FEMS Microbiol. Rev. 35: 620-651.

Krauss, G.-J., Wesenberg, D., Ehrman, J.M. et al. 2008. Responses to heavy metals. In: Novel Techniques and Ideas in Mycology (Eds.: Sridhar, K.R., Bärlocher, F. and Hyde, K.D.). Fungal Diversity Research Series \# 20, Fungal Diversity Press, Yunnan, 149-182.

Krzewicka, B., Smykla, J., Galas, J. and Śliwa, L. 2017. Freshwater lichens and habitat zonation of mountain streams. Limnologica 63: 1-10.

Lennon, J. and S.E. Jones. 2011. Microbial seed banks: The ecological and evolutionary implications of dormancy. Nat. Rev. Microbiol. 9: 119-130.

Lepère, C., Domaizon, I. and Humbert, J.F. 2019. Diversity, spatial distribution and activity of fungi in freshwater ecosystems. Peer J. 7: e6247, 10.7717/peerj.6247

Li, W.C., Zhou, J., Guo, S.Y. and Guo, L.D. 2007. Endophytic fungi associated with lichens in Baihua mountain of Beijing, China. Fungal Divers. 25: 69-80.

Marvanová, L. 2005. Maintenance of aquatic hyphomycete culture. In: Methods to Study Litter Decomposition (Eds.: Graça, M.A.S., Bärlocher, F. and Gessner, M.O.). Springer, Dordrecht, 129-152.

Masigol, H., Khodaparast, S.A., Woodhouse, J.N. et al. 2019. The contrasting roles of aquatic fungi and oomycetes in the degradation and transformation of polymeric organic matter. Limnol. Oceanogr. 9999: $1-17$.

Matura, N., Krzewicka, B. and Flakus, A. 2017. Seven species of freshwater lichen-forming fungi newly recorded from Poland. Pol. Bot. J. 62: 273-278.

Meyers, S.P. 1996. Fifty years of marine mycology: 
Highlights of the past, projections for the coming century. SIMS News 46: 119-127.

Misra, J.K. and Horn, B.W. 2001. Trichomycetes and Other Fungal Groups. Oxford \& IBH Publishing Co. Pvt. Ltd., New Delhi.

Monchy, S., Sanciu, G., Jobard, M. et al. 2011. Exploring and quantifying fungal diversity in freshwater lake ecosystems using rDNA cloning/sequencing and SSU tag pyrosequencing. Environ. Microbiol. 13: 1433-1453.

Moro, L.B., Delgado, G. and Schoenlein-Crusius, I.H. 2018. Freshwater hyphomycetes from Ilhabela State Park, Brazil. Curr. Res. Environ. Appl. Mycol. 8: 204-216.

Mukherji, S., Haldar, S. and Ghosh, A. 2019. Investigation of the structural and functional microbial diversity in Indian mangroves. In: Microorganisms in Saline Environments: Strategies and Functions (Eds.: Giri, S. and Verma, A.). Springer Nature, Switzerland, 93130 .

Naranjo-ortiz , M. and Gabaldón, T. 2019. Fungal evolution: major ecological adaptations and evolutionary transitions. Biol. Rev. 94: 1443-1476.

Nascimbene, J. and Nimis, P.L. 2006. Freshwater lichens of the Italian Alps - A review. Ann. Limnol. Inst. J. Lim. 42: 27-32.

Nawaz, A., Purahong, W., Lehmann, R. et al. 2018. First insights into the living groundwater mycobiome of the terrestrial biosphere. Wat. Res. 145: 50-61.

Nerva, L., Ciuffo, M., Vallino, M. et al. 2016. Multiple approaches for the detection and characterization of viral and plasmid symbionts from a collection of marine fungi. Virus Res. 219: 22-38.

Ogaki, M.B., Coelho, L.C., Vieira, R. et al. 2020. Cultivable fungi present in deep sea sediments of Antarctica: Taxonomy, diversity, and bioprospecting of bioactive compounds. Extremophiles 24: 227-238.

Ogaki, M.B., de Paula, M.T., Ruas, D. 2019. Marine fungi associated with Antarctic macroalgae. In: The Ecological Role of Microorganisms in the Antarctic Environment (Ed.: Castro-Spwomslo. S.). Springer Polar Sciences, 239-255.

Ortiz-Vera, M.P., Olchanheski, L.R., Da Silva, G. 2018. Influence of water quality on diversity and composition of fungal communities in a tropical river. Sci. Rep. 8: 14799, 10.1038/s41598-01833 $162-\mathrm{y}$

Pang, K.L., Guo, S.-Y., Chen, A. et al. 2019. Insights into fungal diversity of a shallow water hydrothermal vent field at Kueishan Island, Taiwan by culturebased and metabarcoding analyses. PLOS ONE 14: e0226616, https://doi.org/10.1371/journal.pone. 0226616

Pang, K.-L., Jheng, J.S. and Jones, E.B.G. 2011. Marine
Mangrove Fungi of Taiwan. National Taiwan Ocean University, Chilung.

Pang, K.-L., Overy, D.P., Jones, E.B.G. et al. 2016. Marine fungi and marine-derived fungi in natural product chemistry research: Toward a new consensual definition. Fungal Biol. Rev. 30: 163-175.

Park, D. 1972. On the ecology of heterotrophic microorganisms in fresh-water. Mycol. Res. 58, 291-299.

Park, M.S., Oh, S.Y., Fong, J.J. et al. 2019. The diversity and ecological roles of Penicillium in intertidal zones. Sci.Rep. 9: 13540

Pascoal, C., Marvanová, L. and Cássio, F. 2005. Aquatic hyphomycete diversity in streams of Northwest Portugal. Fungal Divers. 19: 109-128.

Peay, K.G., Kennedy, P.G. and Talbot, J.M. 2016. Dimensions of biodiversity in the earth mycobiome. Nat. Rev. Microbiol. 14: 435-447.

Raghukumar, C. 2012. Biology of Marine Fungi. SpringerVerlag, Berlin and Heidelberg.

Raghukumar, C. 2019. Fungi in cold deep sea: A hot topic. KAVAKA - Trans. Mycol. Soc. Ind. 52:26-33.

Raghukumar, C. and Damare, S.R. 2008. Deep-sea fungi. In: High-Pressure Microbiology (Eds.: Michiels, C., Bartlett, D.H. and Aertsen, A). ASM Press, Washington DC, 265-292.

Raghukumar, C., Damare, S. and Singh, P. 2010. A review on deep-sea fungi: occurrence, diversity and adaptations. Bot. Mar. 53: 479-492.

Raghukumar, S. 2017. Fungi in Coastal and Oceanic Marine Ecosystems. Springer International Publishing AG, Switzerland.

Raghukumar, S., Raghukumar, C. and Manohar, C.S. 2014. Fungi living in diverse extreme habitats of the marine environment. KAVAKA - Trans. Mycol. Soc. Ind. 42: 145-153.

Raja, H.A., Shearer, C.A. and Tsui, C.K.-M. 2018. Freshwater Fungi. In: eLS Subject Area: Microbiology. John Wiley \& Sons Ltd., Chichester: 10.1002/97804700 15902.a0027210

Raveendran, K. and Manimohan, P. 2007. Marine Fungi of Kerala. Malabar Natural History Society, Calicut, Kerala.

Reich, M. and Labes, A. 2017. How to boost marine fungal research: A first step towards a multidisciplinary approach by combining molecular fungal ecology and natural products chemistry. Mar. Genom. 36: 57 75 .

Richards, T.A., Leonard, G. and Chambouvet, A. 2015. Molecular diversity and distribution of marine fungi across 130 European environmental samples. Proc. Biol. Sci. 282: 20152243, http://dx.doi.org/10.1098/ rspb.2015.2243 
SAC (Space Applications Centre) 2011. National Wetland Atlas. Indian Space Research Organisation, Ahmedabad.

Sakayaroj, J., Preedanon, S., Suetrong, S. et al. 2012. Molecular characterization of basidiomycetes associated with the decayed mangrove tree Xylocarpus granatum in Thailand. Fungal Divers. 56: $145-156$.

Schlosser, D., Solé, M., Wesenberg, D. et al. 2008. Fungal responses to organic pollutants. In: Novel Techniques and Ideas in Mycology (Eds.: Sridhar, K.R., Bärlocher, F, and Hyde, K.D.). Fungal Diversity Research Series \# 20, Fungal Diversity Press, Yunnan, 119-148.

Schmit, J.P. and Shearer. C.A. 2003. A checklist of mangrove associated fungi. Mycotaxon 80: 423-477.

Seena, S., Bärlocher, F., Sobral, O. et al. 2019a. Biodiversity of litter fungi in streams along a latitudinal gradient. Sci. Tot. Environ. 661: 306-315.

Seena, S., Graça, D., Bartels, A. and Cornut, J. 2019b. Does nanosized plastic affect aquatic fungal litter decomposition? Fungal Ecol. 39: 388-392.

Seena, S., Sorbal, O. and Cano, A. 2020. Metabolomic, functional, and ecologic responses of the common freshwater fungus Neonectria lugdunensis to mine drainage stress. Sci. Tot. Environ. 718: 137359, https://doi.org/10.1016/j.scitotenv.2020.137359

Selosse, M.-A., Schneider-Maunoury, L. and Martos, F. 2018. Time to re-think fungal ecology? Fungal ecological niches are often prejudged. New Phytol. 217: 968972.

Shearer, C.A. and Raja, H.A. 2017. Freshwater Ascomycetes and their Anamorphs: http://fungi.life.illinois.edu/

Shearer, C.A., Descals, E., Kohlmeyer, B. et al. 2007. Fungal biodiversity in aquatic habitats. Biodivers. Conserv. 16: 49-67.

Shearer, C.A., Zelski, S.E., Raja, H.A. et al. 2015. Distributional patterns of freshwater ascomycetes communities along an Andes to Amazon elevational gradient in Peru. Biodivers. Conser. 24: 1877-1897.

Singh, J.S. and Chaturvedi, R.K. 2017. Diversity of ecosystem types in India: A review. Proc. Ind. Natn. Sci. Acad. 83: 569-594.

Sivichai, S., and Jones, E.B.G. 2003. Teleomorphicanamorphic connections of freshwater fungi. In: Freshwater Mycology (Eds.: Tsui, C.K.M. and Hyde. K.D.). Fungal Diversity Research Series \# 10, Fungal Diversity Press, Hong Kong, 259-274.

Solé, M., Chatzinotas, A., Sridhar, K.R. et al. 2008a. Improved coverage of fungal diversity in polluted groundwaters by semi-nested PCR. Sci. Tot. Environ. 406: 324-330

Solé, M., Fetzer, I., Wennrich, R. et al. 2008b. Aquatic hyphomycete communities as potential bioindicators for assessing anthropogenic stress. Sci. Tot. Environ. 389: 557-565.

Sridhar, K.R. 2009a. Frontiers in Fungal Ecology, Diversity and Metabolites. IK International Publishing House Pvt. Ltd., New Delhi.

Sridhar, K.R. 2009b. Fungi in the tree canopy - An appraisal. In: Applied Mycology (Eds.: Rai, M. and Bridge, P.). CAB International, UK, 73-91.

Sridhar, K.R. 2017. Marine filamentous fungi: Diversity, distribution and bioprospecting. In: Developments in Fungal Biology and Applied Mycology (Eds.: Satyanarayana, T., Deshmukh, S.K. and Johri, B.N.). Springer Singapore, 59-73.

Sridhar, K.R. 2019. Expedition with micro- and macro-fungi: New perspectives to bridge the gaps. KAVAKA Trans. Mycol. Soc. Ind. 52: 1-19.

Sridhar, K.R. and Kaveriappa, K.M. 1988. Occurrence and survival of aquatic hyphomycetes in brackish and seawater. Arch. Hydrobiol. 113: 153-160.

Sridhar, K.R., Bäerlocher, F. and Hyde, K.D. 2008b. Novel Techniques and Ideas in Mycology. Fungal Diversity Research Series \# 20, Fungal Diversity Press, Yunnan.

Sridhar, K.R., Bärlocher, F., Wennrich, R. et al. 2008a. Fungal biomass and diversity in sediments and on leaf litter in heavy metal contaminated waters of Central Germany. Fund. Appl. Limnol. 171: 63-74.

Sridhar, K.R., Krauss, G., Bärlocher, F. et al. 2000. Fungal diversity in heavy metal polluted waters in Central Germany. Fungal Divers 5: 119-129.

Stibor, H., Stockenreiter, M., Nejstgaard, J.C. et al. 2019. Trophic switches in pelagic systems. Curr. Opin. Syst. Biol. 13: 108-114.

Suberkropp, K. and Klug, M. J. 1980. The maceration of deciduous leaf litter by aquatic hyphomycetes. Can . J. Bot. 58, 1025-1031.

Talbot, J.M., Burns, T.D., Taylor, J.W. et al. 2014. Endemism and functional convergence across the North American soil mycobiome. Proc. Natl Acad. Sci. 111, 6431-6346.

Tedersoo, L., Tooming-Klunderud, A. and Anslan, S. 2018. PacBio metabarcoding of fungi and other eukaryotes: errors, biases and perspectives. New Phytol. 217, 1370-1385.

Thüs, H., Aptroot, A. and Seaward, M.R.D. 2014. Freshwater lichens. In: Freshwater fungi: and Fungal-Like Organisms (Eds.: Jones, E.B.G., Hyde, K.D. and Pang, K.-L.). Walter de Gruyter GmbH \& Co KG, Germany, 333-358.

Tisthammer, K.H., Cobian, G.M. and Amend, A.S. 2016. Global biogeography of marine fungi is shaped by the environment. Fungal Ecol. 19: 39-48. 
Tolkkinen, M.J., Heio, J., Ahonen, S.H.K. et al. 2020. Streams and riparian forests depend on each other: A review with a special focus on microbes. For. Ecol. Manage. 642: 117962, https://doi.org/10.1016/j. foreco. 2020.117962

Tsui, C.K.M. and Hyde, K.D. 2003. Freshwater Mycology. Fungal Diversity Research Series \# 10. Fungal Diversity Press, Hong Kong.

Vass, M., Révay, Á, Kucserka, T. et al. 2013. Aquatic hyphomycetes as survivors and/or first colonizers after a red sludge disaster in the Torna stream, Hungary. Int. Rev. Hydriobiol.98: 1-8.

Venkatachalam, A., Thirunavukkarasu, N. and Suryanarayanan, T.S. 2015. Distribution and diversity of endophytes in seagrasses. Fungal Divers. 13: 60-65.

Venkataraman, K. 2011. Coral reefs of India. Encyclopedia of Modern Coral Reef 267-275.

Wainwright, B.J., Bauman, A.G., Zahn, G.L. et al. 2019. Characterization of fungal biodiversity and communities associated with the reef macroalga Sargassum ilicifolium reveals fungal community differentiation according to geographic locality and algal structure. Marine Biodivers. 49: 2601-2608.
Wood-Eggenschwiler, S. and Bärlocher, F. 1985. Geographical distribution of Ingoldian fungi. Verh. Int. Ver. Limnol. 22: 2780-2785.

WTO (Wetlands and World Tourism Organization). 2012. Ramsar Convention, Destination Wetlands: Supporting Sustainable Tourism. The Secretariat of the Convention on Wetlands and World Tourism Organization, Gland and Madrid.

Wurzbacher, C.M., Bärlocher, F. and Grossart, H.-P. 2010. Fungi in lake ecosystems. Aquat. Microb. Ecol. 59: 125-149.

Zhao, G.Z., Liu, X.Z, and Wu, W.P. 2007. Helicosporous hyphomycetes from China. Fungal Divers. 26: 313524.

Zingel, P., Cremona, F., Nõges, T. et al. 2018. Effects of warming and nutrients on the microbial food web in shallow lake mesocosms. Eur. J. Parasitol. 64: 1-12.

Zuccaro, A. and Mitchell. J.I. 2005. Fungal communities of seaweeds. In: The Fungal Community (Eds.: Deighton, J., White, J.F. and Oudemans, P. ). CRC Press, Taylor and Francis, New York, 533-580. 